\title{
Agrobacterium-MEDIATED GENETIC TRANSFORMATION OF POTATO FOR ABIOTIC STRESS TOLERANCE
}

\author{
S. N. Begam, K. M. Nasiruddin, M. S. Haque and S. Yasmin'1 \\ Department of Biotechnology, Bangladesh Agricultural University \\ Mymensingh-2202, Bangladesh
}

\begin{abstract}
Two potato varieties, Cardinal and Heera, were used to optimize the Agrobacterium-mediated genetic transformation system in potato for abiotic stress tolerance. MS medium supplemented with different concentrations and combinations of NAA and BAP were used to obtain callus induction from leaf explants of potato $\mathrm{cv}$ Cardinal and Heera. Maximum percentage of callus induction (95.83\%) was observed in MS medium supplemented with $4 \mathrm{mg} / \mathrm{L}$ NAA and $2 \mathrm{mg} / \mathrm{L}$ BAP. The highest callusing was found in Cardinal and the lowest in Heera. Calluses were inoculated with Agrobacterium tumefaciens strain LBA4404 (pB1121) carrying CIPK sense gene, selectable marker gene nptII gene conferring resistance to kanamycin and the GUS reporter gene. Both the varieties were found GUS positive after inoculation and selection. Cardinal had maximum percentage of survived callus $(25 \%)$ on selection media. Stable intregration and expression of the transgenes were confirmed by GUS histochemical assay.
\end{abstract}

Key words : Potato, Agrobacterium mediated transformation, Abiotic stress

\section{INTRODUCTION}

Potato (Solanum tubersum L.) belongs to the family Solanaceae. It is one of the most agronomically important plants in the world, notably due to its high productivity and its high starch, vitamin and protein content. In the recent years, there has been an increasing trend in both area and production of potato in Bangladesh. But the yield per unit area is not satisfactory. In Bangladesh, 4856 thousand tons of potatoes were produced in 2005 (BBS, 2005). Biotic and abiotic factors are responsible for the low yield of potato which may exert a deleterious effect on yield, marketable quality, storability, germplasm conservation, distribution and international exchange. Abiotic stresses include drought, salinity, extreme temperatures, chemical toxicity and oxidative stress and are serious threats to agriculture and the natural states of environment (Wang et al., 2003). The population of our country is increasing day by day but the land is decreasing. Therefore, we need to utilize the lands which are now not under cultivation, such as, coastal zone which have high saline properties. Furthermore, the crop is damaged by a series of environmental stresses like drought during the development of roots or tubers. Abiotic stress limits plant growth and significantly increases the negative effects on both quantity and quality of crop production (Mohsin, 2004). Crop varieties resistant to abiotic stresses

Correspondence:- E-mail: sabinay_bt@yahoo.com 
need to be developed by using molecular tools of biotechnology. Agrobacteriummediated genetic transformation may be the best option for potato as traditional breeding is not possible in this vegetatively propagated crop. Genetic transformation needs a reliable regeneration protocol. The present research work has been undertaken to optimize the Agrobacterium- mediated genetic transformation system for abiotic stress tolerance.

\section{MATERIALS AND METHODS}

The present investigation was carried out in the Biotechnology Laboratory of the Department of Biotechnology, Bangladesh Agricultural University, Mymensingh. Two varieties of potato (Cardinal and Heera) were used in the experiment. Leaf explants were used for callus induction. The induced calli were then used for Agrobacterium-mediated genetic transformation. Genetically engineered Agrobacterium tumefaciens strain LBA4404 (pB1121) containing the uidA gene encoding GUS ( $\beta$-glucuronidase), the nptII gene and the CIPK sense gene encoding calcineurin B-like protein conferring abiotic stress tolerance driven by CaMV promoter and NOS terminator within the right border (RB) and left border (LB) region of the construct was used. For the induction and maintenance of callus from leaf, MS (Murashige and Skoog, 1962) medium containing different concentrations and combinations of BAP $(0,2,4$ and $6 \mathrm{mg} / \mathrm{L})$ and NAA $(0,1,2$ and $4 \mathrm{mg} / \mathrm{L})$ was used. YMB medium was used for Agrobacterium culture aintenance and LB medium was used as Agrobacterium working culture medium for transformation. Calli were infected in liquid bacterial strain and co-cultivated for 3 days on the MS medium without growth regulators. After co-cultivation, explants were washed with sterile water with added cefotaxime $(500 \mathrm{mg} / \mathrm{l})$ and transferred onto MS medium supplemented with $3 \mathrm{mg} / \mathrm{L}$ NAA, $4 \mathrm{mg} / \mathrm{L}$ BAP and $200 \mathrm{mg} / \mathrm{L}$ cefotaxime. For low selection, MS medium supplemented with, $3 \mathrm{mg} / \mathrm{L}$ NAA and $4 \mathrm{mg} / \mathrm{L} \mathrm{BAP,} 20 \mathrm{mg} / \mathrm{L}$ kanamycin and $100 \mathrm{mg} / \mathrm{L}$ cefotaxime was used. For high selection and regeneration, MS medium supplemented with $3 \mathrm{mg} / \mathrm{L}$ NAA and $4 \mathrm{mg} / \mathrm{L} \mathrm{BAP}, 40 \mathrm{mg} / \mathrm{L}$ kanamycin and $100 \mathrm{mg} / \mathrm{L}$ cefotaxime was used. Transformation ability was assessed through histochemecal assay of GUS reporter gene in callus tissue. The experiments were laid in Completely Randomized Design (CRD) with three replications. The analyses of variances for different parameters were performed and means were compared by the Duncan's Multiple Range Test (DMRT).

\section{RESULTS AND DISCUSSION}

The ultimate goal of this experiment was to establish a suitable system for Agrobacteriummediated genetic transformation in potato and also determine the effect of varieties, antibiotics, inoculation time and co-cultivation periods on transformation.

Among the varieties Cardinal showed the higher percentage of callus (47.66\%) than Heera (39.58\%) (Table 1). It required more time for callus induction (11.50 days) than Heera (11.46 days) (Table 1). The effect of different concentrations of NAA and BAP on per cent callus induction indicated that MS medium supplemented with $4 \mathrm{mg} / \mathrm{L} \mathrm{NAA}$ showed the highest percentage $(57.81 \%)$ of callus induction. Among the BAP 
concentrations $2 \mathrm{mg} / \mathrm{L}$ BAP gave the highest percentage $(60.42 \%)$ of callus induction. Similar result was observed by Juan et al. (2004). The minimum number of days required for callus initiation (10.16 day) was observed in $4 \mathrm{mg} / \mathrm{L}$ NAA. Among the BAP concentrations, $2 \mathrm{mg} / \mathrm{L}$ BAP required minimum number of days for callus initiation (13.47 day) (Table 1$)$.

Table 1. Effect of variety on number of calli/vial, per cent callus induction and days to callus induction

\begin{tabular}{ccccc}
\hline Variety/Hormone $(\mathrm{mg} / \mathrm{l})$ & Number of calli/vial & $\begin{array}{c}\text { Per cent callus } \\
\text { induction }\end{array}$ & $\begin{array}{c}\text { Days to callus } \\
\text { induction }\end{array}$ \\
\hline Variety & Cardinal & $3.25 \mathrm{a}$ & $47.66 \mathrm{a}$ & $11.50 \mathrm{a}$ \\
& Heera & $2.75 \mathrm{~b}$ & $39.58 \mathrm{~b}$ & $11.46 \mathrm{~b}$ \\
\hline Hormone NAA 0 & $2.22 \mathrm{~d}$ & $36.46 \mathrm{c}$ & $13.35 \mathrm{a}$ \\
& $3.06 \mathrm{~b}$ & $39.06 \mathrm{bc}$ & $10.44 \mathrm{c}$ \\
2 & $2.47 \mathrm{c}$ & $41.15 \mathrm{~b}$ & $11.97 \mathrm{~b}$ \\
4 & $4.25 \mathrm{a}$ & $57.81 \mathrm{a}$ & $10.16 \mathrm{c}$ \\
\hline 2 & $1.50 \mathrm{c}$ & $0.00 \mathrm{c}$ & $0.00 \mathrm{~d}$ \\
4 & $3.63 \mathrm{a}$ & $60.42 \mathrm{a}$ & $13.47 \mathrm{c}$ \\
6 & $3.50 \mathrm{ab}$ & $57.81 \mathrm{ab}$ & $50.30 \mathrm{~b}$ \\
\hline
\end{tabular}

Six calli were cultured vial. Figures within the same column bearing different letters are significantly different at $0.05 \%$ level according to DMRT.

Combined effect of variety and different concentrations of NAA and BAP was highly significant. The highest percentage of callus (95.83\%) was observed in Cardinal with MS medium containing $4 \mathrm{mg} / \mathrm{L}$ NAA and $2 \mathrm{mg} / \mathrm{L}$ BAP and lowest percentage of callus $(41.67 \%)$ was observed in Heera with MS medium containing $2 \mathrm{mg} / \mathrm{L}$ NAA and $2 \mathrm{mg} / \mathrm{L}$ BAP (Table 2). Minimum number of days (8.50 days) was required for Cardinal at $4 \mathrm{mg} / \mathrm{L}$ NAA and $2 \mathrm{mg} / \mathrm{L}$ BAP compared to any other combination and maximum number of days (20.00 days) was required medium without NAA and with $6 \mathrm{mg} / \mathrm{L}$ BAP. In case of Heera, minimum number of days (11.25 day) was required in medium supplemented with $1 \mathrm{mg} / \mathrm{L}$ $\mathrm{NAA}$ and $4 \mathrm{mg} / \mathrm{L} \mathrm{BAP}$ and maximum number of days (22.50 day) was required in medium containing $6 \mathrm{mg} / \mathrm{L}$ BAP and without NAA (Table 2).

Higher survival potentiality was observed in $20 \mathrm{mg} / \mathrm{L}$ (20.83\%) than $40 \mathrm{mg} / \mathrm{L}$ kanamycin. (Table 3). In case of Agrobacterium-mediated transformation experiments inoculation time and duration are important factors. Calli showed higher response $(61.11 \%)$ to the assay in case of 7 minutes inoculation time (Table 4). The calli co-cultivated for 5 days duration gave higher $(58.33 \%$ ) response to the GUS assay (Table 4$)$. Both the two varieties showed positive response towards transformation. Cardinal showed higher $(55.56 \%)$ and Heera showed lower response (35.19\%) to GUS assay (Table 4). Sultan el al. (2000) also reported that Cardinal showed better response to transformation. Yen et al. (2000) mentioned that shorter 
co-cultivation times resulted in higher number of explants survival. The combined effect of variety, inoculation times and co-cultivation periods were statistically non significant. Cardinal with $7 \mathrm{~min}$ inoculation time and 5 days co-cultivation periods gave the highest GUS positive assay $(100 \%)$ and the lowest $(16.67 \%)$ was observed in Heera with 3 min inoculation time and 3 days co-cultivation periods that were identical with $3 \mathrm{~min}$ inoculation time and 3 days co-cultivation periods (Table 5).

Table 2. Combined effect of variety, different concentrations of NAA and BAP on number of calli/vial, per cent callus induction and days to callus induction

\begin{tabular}{|c|c|c|c|c|c|}
\hline \multirow[t]{2}{*}{ Variety } & \multicolumn{2}{|c|}{ Treatment combinations } & \multirow{2}{*}{$\begin{array}{c}\text { Number of } \\
\text { calli/vial }\end{array}$} & \multirow{2}{*}{$\begin{array}{l}\text { Per cent callus } \\
\text { induction }\end{array}$} & \multirow{2}{*}{$\begin{array}{l}\text { Days to callus } \\
\text { induction }\end{array}$} \\
\hline & NAA $(\mathrm{mg} / \mathrm{L})$ & $\mathrm{BAP}(\mathrm{mg} / \mathrm{L})$ & & & \\
\hline \multirow[t]{16}{*}{ Cardinal } & \multirow{6}{*}{0} & 0 & $0.00 \mathrm{f}$ & $0.00 \mathrm{f}$ & $0.00 \mathrm{i}$ \\
\hline & & 2 & $3.25 \mathrm{~d}$ & $54.17 \mathrm{~d}$ & $15.50 \mathrm{de}$ \\
\hline & & 4 & 2.75 de & $41.67 \mathrm{e}$ & $18.75 \mathrm{~b}$ \\
\hline & & 6 & $3.25 \mathrm{~d}$ & $54.17 \mathrm{~d}$ & $20.00 \mathrm{~b}$ \\
\hline & & 0 & $2.75 \mathrm{de}$ & $0.00 \mathrm{f}$ & $0.00 \mathrm{i}$ \\
\hline & & 2 & $2.75 \mathrm{de}$ & 45.83 de & $11.50 \mathrm{fg}$ \\
\hline & \multirow[t]{3}{*}{1} & 4 & $4.50 \mathrm{bc}$ & $75.00 \mathrm{bc}$ & 13.50 defg \\
\hline & & 6 & $3.25 \mathrm{~d}$ & $54.17 \mathrm{~d}$ & $18.00 \mathrm{bc}$ \\
\hline & & 0 & $0.00 \mathrm{f}$ & $0.00 \mathrm{f}$ & $0.00 \mathrm{i}$ \\
\hline & \multirow{4}{*}{2} & 2 & $4.50 \mathrm{bc}$ & $75.00 \mathrm{bc}$ & 15.50 de \\
\hline & & 4 & $4.00 \mathrm{c}$ & $66.67 \mathrm{c}$ & 15.25 de \\
\hline & & 6 & $3.25 \mathrm{~d}$ & $54.17 \mathrm{~d}$ & $18.25 \mathrm{~b}$ \\
\hline & & 0 & $3.25 \mathrm{~d}$ & $0.00 \mathrm{f}$ & $0.00 \mathrm{i}$ \\
\hline & \multirow{3}{*}{4} & 2 & $5.75 \mathrm{a}$ & $95.83 \mathrm{a}$ & $8.50 \mathrm{~h}$ \\
\hline & & 4 & $4.25 \mathrm{bc}$ & $70.83 \mathrm{bc}$ & 13.25 efg \\
\hline & & 6 & $4.50 \mathrm{bc}$ & $75.00 \mathrm{bc}$ & $16.00 \mathrm{~cd}$ \\
\hline \multirow[t]{16}{*}{ Heera } & \multirow{6}{*}{0} & 0 & $0.00 \mathrm{f}$ & $0.00 \mathrm{f}$ & $0.00 \mathrm{i}$ \\
\hline & & 2 & $3.00 \mathrm{de}$ & $50.00 \mathrm{de}$ & 14.50 de \\
\hline & & 4 & $2.75 \mathrm{de}$ & 45.83 de & 15.55 de \\
\hline & & 6 & $2.75 \mathrm{de}$ & 45.83 de & $22.50 \mathrm{a}$ \\
\hline & & 0 & $3.00 \mathrm{de}$ & $0.00 \mathrm{f}$ & $0.00 \mathrm{i}$ \\
\hline & & 2 & $2.50 \mathrm{e}$ & $41.67 \mathrm{e}$ & 14.75 de \\
\hline & \multirow[t]{2}{*}{1} & 4 & $3.00 \mathrm{de}$ & $50.00 \mathrm{de}$ & $11.25 \mathrm{~g}$ \\
\hline & & 6 & $2.75 \mathrm{de}$ & 45.83 de & 14.50 de \\
\hline & \multirow{5}{*}{2} & 0 & $0.00 \mathrm{f}$ & $0.00 \mathrm{f}$ & $0.00 \mathrm{i}$ \\
\hline & & 2 & $2.50 \mathrm{e}$ & $41.67 \mathrm{e}$ & 13.75 def \\
\hline & & 4 & $2.50 \mathrm{e}$ & $41.67 \mathrm{e}$ & $18.75 \mathrm{~d}$ \\
\hline & & 6 & $3.00 \mathrm{de}$ & 50.00 de & 14.25 de \\
\hline & & 0 & $3.00 \mathrm{de}$ & $0.00 \mathrm{f}$ & $0.00 \mathrm{i}$ \\
\hline & \multirow{3}{*}{4} & 2 & $4.75 \mathrm{~b}$ & $79.17 \mathrm{~b}$ & 13.75 def \\
\hline & & 4 & $4.25 \mathrm{bc}$ & $70.83 \mathrm{bc}$ & 14.75 de \\
\hline & & 6 & $4.25 \mathrm{bc}$ & $70.83 \mathrm{bc}$ & $15.00 \mathrm{de}$ \\
\hline
\end{tabular}

Six calli were cultured/vial. Figures within the same column bearing different letters are significantly different at $0.05 \%$ level according to DMRT 
Table 3. Main effect of kanamycin on number of survived calli/vial and per cent survived calli

\begin{tabular}{ccc}
\hline Kanamycin & Number of survived calli/Vial & \% survived calli \\
\hline $20 \mathrm{mg} / \mathrm{L}$ & $1.25 \mathrm{a}$ & $20.83 \mathrm{a}$ \\
$40 \mathrm{mg} / \mathrm{L}$ & $0.88 \mathrm{~b}$ & $14.58 \mathrm{~b}$ \\
\hline
\end{tabular}

Six calli were cultured vial. Figures within the same column bearing different letters are significantly different at $0.05 \%$ level according to DMRT.

Table 4. Main effect of variety on \% GUS positive explants

\begin{tabular}{cc}
\hline Variety & \% GUS positive explants \\
\hline Cardinal & $55.56 \mathrm{a}$ \\
Heera & $35.19 \mathrm{~b}$ \\
Inoculation time (minute) & \\
3 & $22.22 \mathrm{c}$ \\
5 & $52.78 \mathrm{~b}$ \\
7 & $61.11 \mathrm{a}$ \\
Co-cultivation period (days) & $30.56 \mathrm{c}$ \\
3 & $47.22 \mathrm{~b}$ \\
4 & $58.33 \mathrm{a}$ \\
\hline
\end{tabular}

Six calli were cultured vial. Figures within the same column bearing different letters are significantly different at $0.05 \%$ level according to DMRT.

Table 5. Combined effect of inoculation time, co-cultivation periods on \% GUS positive assay

\begin{tabular}{|c|c|c|c|c|}
\hline Variety & $\begin{array}{l}\text { Inoculation } \\
\text { time (minute) }\end{array}$ & $\begin{array}{l}\text { Co-cultivation } \\
\text { period (days) }\end{array}$ & $\begin{array}{l}\text { Number of explants } \\
\text { positive for GUS }\end{array}$ & $\begin{array}{c}\% \text { GUS positive } \\
\text { explants }\end{array}$ \\
\hline \multirow[t]{9}{*}{ Cardinal } & 3 & 3 & $1.00 \mathrm{f}$ & $16.67 \mathrm{f}$ \\
\hline & & 4 & $2.00 \mathrm{de}$ & $33.33 \mathrm{de}$ \\
\hline & & 5 & $3.00 \mathrm{~d}$ & $50.00 \mathrm{~d}$ \\
\hline & 5 & 3 & $3.00 \mathrm{~d}$ & $50.00 \mathrm{~d}$ \\
\hline & & 4 & $3.00 \mathrm{~d}$ & $50.00 \mathrm{~d}$ \\
\hline & & 5 & $4.00 \mathrm{c}$ & $66.67 \mathrm{c}$ \\
\hline & 7 & 3 & $3.00 \mathrm{~cd}$ & $50.00 \mathrm{~cd}$ \\
\hline & & 4 & $5.00 \mathrm{~b}$ & $83.33 \mathrm{~b}$ \\
\hline & & 5 & $6.00 \mathrm{a}$ & $100.00 \mathrm{a}$ \\
\hline \multirow[t]{9}{*}{ Heera } & 3 & 3 & $0.00 \mathrm{~g}$ & $0.00 \mathrm{~g}$ \\
\hline & & 4 & $1.00 \mathrm{f}$ & $16.67 \mathrm{f}$ \\
\hline & & 5 & $1.00 \mathrm{f}$ & $16.67 \mathrm{f}$ \\
\hline & 5 & 3 & $2.00 \mathrm{de}$ & $33.33 \mathrm{de}$ \\
\hline & & 4 & $3.00 \mathrm{~d}$ & $50.00 \mathrm{~d}$ \\
\hline & & 5 & $4.00 \mathrm{C}$ & $66.67 \mathrm{c}$ \\
\hline & 7 & 3 & $2.00 \mathrm{e}$ & $33.33 \mathrm{e}$ \\
\hline & & 4 & $3.00 \mathrm{~d}$ & $50.00 \mathrm{~d}$ \\
\hline & & 5 & $3.00 \mathrm{~d}$ & $50.00 \mathrm{~cd}$ \\
\hline
\end{tabular}

Six calli were cultured vial. Figures within the same column bearing different letters are significantly different at $0.05 \%$ level according to DMRT. 

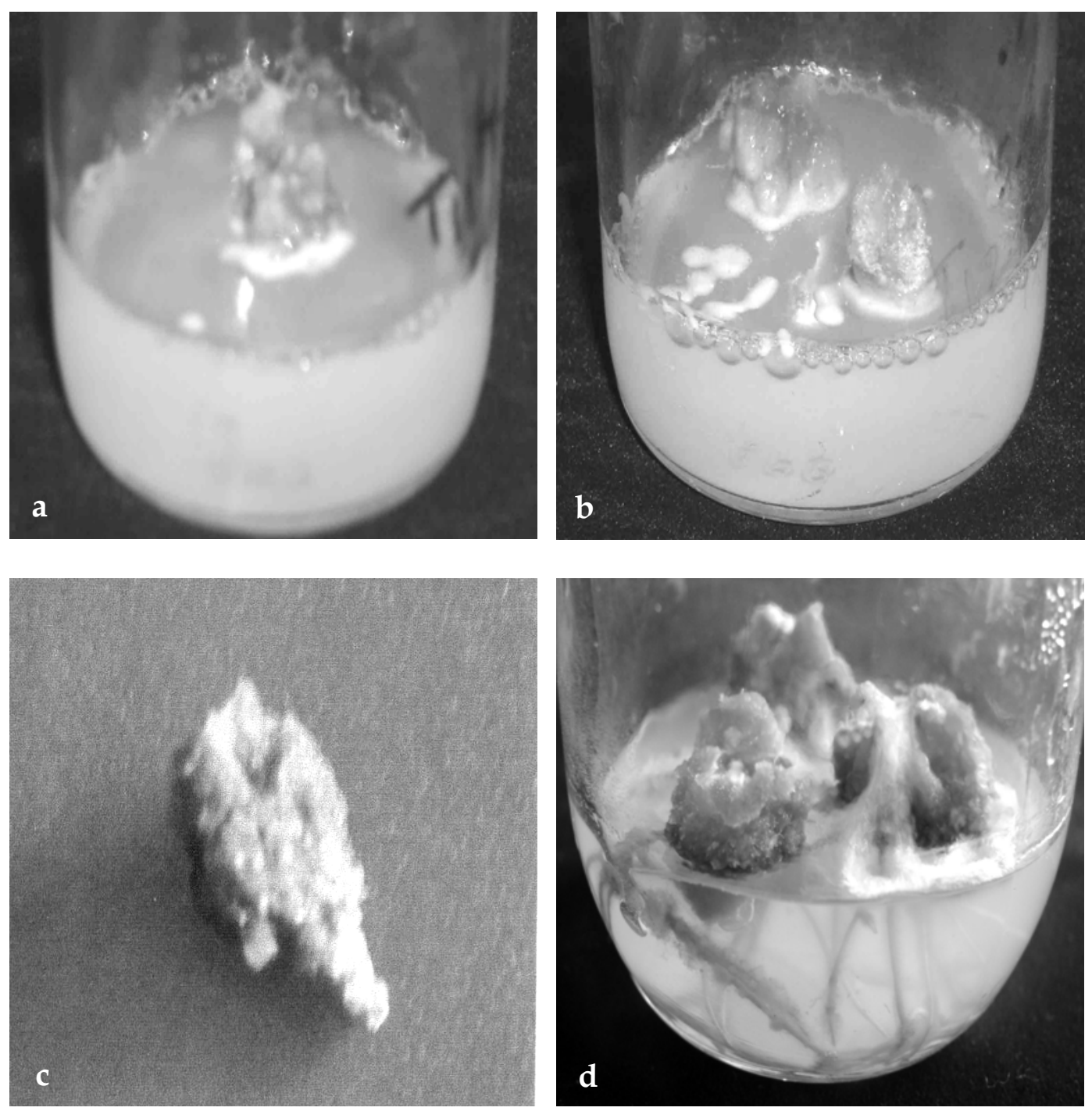

Plate 1. (a) Calli of potato cv. Cardinal treated with kanamycin $(40 \mathrm{mg} / \mathrm{L})$, (b) Selection of kanamycin resistance calli of potato cv. Heera, (c) GUS positive tissue of potato cV. Cardinal and (d) Roots obtained from cv. Cardinal on regeneration medium.

After antibiotic treatment the survived calli were transferred to regeneration medium. The regeneration medium comprised with MS medium containing $3 \mathrm{mg} / \mathrm{L}$ NAA and 4 $\mathrm{mg} / \mathrm{L} \mathrm{BAP}, 100 \mathrm{mg} / \mathrm{L}$ cefotaxime and $40 \mathrm{mg} / \mathrm{L}$ kanamycin and root was obtained from three Cardinal and two Heera calli (Plate 1). The system developed here would be used for the introduction of agronomically important trait in potato and regeneration of transgenic plants. However, more studies should be conducted including molecular analysis of transgenic plants. 


\section{REFERENCES}

BBS. 2005. Monthly statistical bulletin (December). Bangladesh bureau of statistics. Bangladesh Secretarial, Dhaka-1000. p. 55.

Juan, I. Z., Cheng, H. and Zhang, G. Y. 2004. Establishment of efficient regeneration system from leaf explants of potato. Acta Botanica Boreali Occidentalia Sinica., 24(4): 610-614.

Mohsin, M. A. M. 2004. Introduction of salt tolerance in tobacco using a vacular $\mathrm{Va}^{+} / \mathrm{H}^{+}$antiporter gene AVPI from 'Arabidopsis' transgenic approach. M. Phil. Res. Semi, NIBGE.

Murashige, T. and Skoog, F. 1962. A revised medium for rapid growth bioassays with tobacco tissue cultures. Physiol. Plant., 15: 473-497.

Sultana, P. 2000. Agrobacterium-mediated genetic transformation in potato (Solanum tuberosum L.). MS Thesis, Department Botany, University of Dhaka.

Wang, W., Vinocur, B. and Altman A. 2003. Plant response to drought, salinity and extreme temp. towards genetic engineering for stress tolerance. Planta., 218. 1-4.

Yen, B., Reddy, M. S. S., Collins, G. B. and Dinkins, R. D. 2000. Agrobacterium tumefaciens mediated transformation of soybean [Glycine max (L.) merriell] using immature zygotic cotyledon explants. Plant Cell Rep., 19(11): 1090-1097. 